Prof. H. Kimura: Royal Astronomical Society Medallist

THF Gold Medal of the Royal Astronomical Society has been awarded to Prof. H. Kimura, director of the International Latitude Observatory, Mizusawa, Japan, since 1899 , for his valuable work on the variation of latitude. When the scheme for international co-operation was decided upon, the observing programme was drawn up by Prof. Kimura. From the very first year's observations he pointed out that the observed change of latitude at the different stations gave large residuals when analysed in the form $x \cos \lambda+y \sin \lambda$ where $\lambda$ is the longitude, but that these were greatly reduced when a common term known as the $Z$ term was introduced. The existence of this term with an annual period has been verified by later observations, although its origin has not been fully cleared up. When the International Astronomical Union took over the discussion of the international observations from the Central Bureau at Potsdam, Prof. Kimura was naturally placed in charge of it, with the work of reducing and co-ordinating the observations made at the different stations. Under his direction the work has increased considerably, and he was to a large extent instrumental in securing the restarting of the latitude station at Gaithersburg and the starting of a new station at Kitab (in place of the former station at Tschardjui) on the northern parallel, in addition to the commencement of regular observations in the southern hemisphere at La Plata and Adelaide and at a station near the equator in Java.

\section{Unemployment among Professional Workers}

A RECENT report of the International Labour Office indicates that, during the last two years, unemployment among professional workers has continued to increase, and that there is scarcely a country or a profession which has not been acutely affected. In Poland, estimates in March 1935 of the director of the Vocational Re-training Institute for Professional Workers showed that about 170,000 out of 570,000 professional workers in that country (including salaried employees) were without employment. In Switzerland at the beginning of 1935, the number of technical workers (engineers, chemists, etc.) registered with the employment offices was 6,000 , while the number of non-registered unemployed was estimated to be at least 1,000; the total, 7,000, represents more than 30 per cent of the professional workers in Switzerland. Between 1913 and 1932 the increase in the number of students, which varied from 30 to 3 per cent, greatly exceeded the increase in the population of the world. Thus in Germany and in the United States of America, the number of inhabitants per student fell in that period from 866 to 506 and 237 to 127, respectively. In Holland, the ratio similarly fell from 1,229 to 636 . It is considered that in Germany 10,000 university graduates are needed each year to fill vacant posts, but between 1925 and 1933, the average number of persons leaving the universities was 25,000 a year. From these figures, it is easy to see why the estimated number of unemployed university graduates in Germany was so high as 50,000 in 1933 .
THe position with regard to the medical profossion is similar. Gormany requires about 1,800-2,000 new medical men each year, but the universities will supply about 4,000-5,000 medical graduates each year until 1938. Similarly, about 1,000 young dentists will, for some time to come, compete each year for 250 possible appointments, and the number of persons qualifying every year as pharmacists for the noxt four years will be twice as great as the demand. In the United States in 1932, only about 3,000 posts were available for 5,000 young doctors leaving the medical schools, while Dr. E. Cohen, discussing this subject in the Chemische Weekblad (32, 574 (1935)), pointed out that while Folland and the Dutch Indies could normally only offer about 40 posts a year for qualified chemists, hundreds were completing university courses in chemistry. The International Labour Office inquiry indicates that in some professions a certain amount of unemployment is due to the evolution of technical methods and change independent of the present industrial depression, and that in certain professions and countries a considerable amount of professional unemployment existed prior to the present depression.

\section{Development of the Indian Paint Industry}

IN a recent article entitled "Some Lines of Development of the Indian Paint Industry" (Current Science, November 1935), N. Srinivasan deals with the possibilities of developing the paint and cortain allied industries in India. There is, of course, already quite a considerable paint-manufacturing industry in India, partly Indian owned and partly in the hands of branch English firms, but it is contended that insufficient use is made of the raw materials available in India, notably barytes (in Madras and Alwar), lead and zinc ore (in Burma), titaniferous ore (in Travancore) and earth colours. The appeal continues for manufacture in India of the whole range of chemical pigments--the artificial oxides of iron, lead chromes, Prussian blues, Brunswick greens, ultramarine and organic lake colours. In due course, some of these operations may be carried out economically and profitably in India, but it should be pointed out that it is a far cry from a barytes mine to a successful lithopone plant; and to suggest, speaking of manufacturing titanium pigment, that only "enterprise is needed for starting a large modern plant with careful scientific control and intelligent commercial direction" indicates failure to appreciate the extent and manner in which this class of manufacturing operation is tied in with, and can only be considered as a part of, the heavy chemical industry.

A Review is then given of the principal types of paints which might be made in India, and concludes that the modern synthetic and nitrocellulose finishes are likely to be too expensive for the Indian market, and that present effort should be directed to the manufacture of simple linseed oil types, provided they are "quick setting". The particular interest of Mr. Srinivasan is a linseed oil emulsion paint, made up with a protein size extracted from indigenous 